\title{
Tax-deductible provisions for gluten-free diet in Canada compared with systems for gluten-free diet coverage available in various countries
}

\author{
Maria Ines Pinto-Sanchez MD MSc ${ }^{1}$, Elena F Verdu MD PhD ${ }^{1}$, Maria C Gordillo CPA CGA², Julio C Bai MD², \\ Stephen Birch BA MSc DPhil ${ }^{4}$, Paul Moayyedi MD BSc MB ChB PhD MPH ${ }^{1}$, Premysl Bercik MD ${ }^{1}$
}

MI Pinto-Sanchez, EF Verdu, MC Gordillo, et al. Tax-deductible provisions for gluten-free diet in Canada compared with systems for gluten-free diet coverage available in various countries. Can J Gastroenterol Hepatol 2015;29(2):104-110.

Celiac disease affects $1 \%$ of the North American population, with an estimated 350,000 Canadians diagnosed with this condition. The disease is triggered by the ingestion of gluten, and a lifelong, strict glutenfree diet (GFD) is the only currently available treatment. Compliance with a strict GFD is essential not only for intestinal mucosal recovery and alleviation of symptoms, but also for the prevention of complications such as anemia, osteoporotic fractures and small bowel lymphoma. However, a GFD is difficult to follow, socially inconvenient and expensive. Different approaches, such as tax reduction, cash transfer, food provision, prescription and subsidy, have been used to reduce the additional costs of the GFD to patients with celiac disease. The current review showed that the systems in place exhibit particular advantages and disadvantages in relation to promoting uptake and compliance with GFD. The tax offset system used in Canada for GFD coverage takes the form of a reimbursement of a cost previously incurred. Hence, the program does not help celiac patients meet the incremental cost of the GFD - it simply provides some future refund of that cost. An ideal balanced approach would involve subsidizing glutenfree products through controlled vouchers or direct food provision to those who most need it, independently of 'ability or willingness to pay'. Moreover, if the cost of such a program is inhibitive, the value of the benefits could be made taxable to ensure that any patient contribution, in terms of additional taxation, is directly related to ability to pay. The limited coverage of GFD in Canada is concerning. There is an unmet need for GFD among celiac patients in Canada. More efforts are required by the Canadian medical community and the Canadian Celiac Association to act as agents in identifying ways of improving resource allocation in celiac disease.

Key Words: Celiac disease; Gluten-free diet; Subsidy; Tax deduction

\section{Les déductions d'impôt applicables au régime sans gluten au Canada comparées aux couvertures offertes dans divers pays}

La maladie coliaque touche $1 \%$ de la population nord-américaine, et on estime que 350000 Canadiens sont diagnostiqués. Le seul traitement connu de cette maladie qui est déclenchée par l'ingestion de gluten est un régime sans gluten (RSG) rigoureux respecté tout au long de la vie. En effet, il est essentiel de respecter rigoureusement le RSG, non seulement pour le rétablissement de la muqueuse intestinale et le soulagement des symptômes, mais également pour la prévention de complications comme l'anémie, les fractures ostéoporotiques et le lymphome du grêle. Cependant, le RSG est difficile à respecter, peu pratique en société et coûteux. Diverses démarches, telles qu'une réduction d'impôt, un transfert d'argent, un approvisionnement, une prescription et une subvention, ont été privilégiées pour réduire les coûts supplémentaires attribuables au RSG chez les patients atteints d'une maladie cœeliaque. La présente analyse révèle que les systèmes en place comportent certains avantages et désavantages lorsqu'il est question de promouvoir l'adoption et le respect du RSG. Le système de déduction fiscale utilisé au Canada pour couvrir le RSG consiste à rembourser des coûts déjà engagés. Ainsi, le programme n'aide pas les patients à payer les coûts supplémentaires du RSG, mais s'associe simplement à un futur remboursement de ces coûts. La démarche équilibrée et idéale consisterait à subventionner les produits sans gluten au moyen de coupons contrôlés ou d'approvisionnement alimentaire direct aux personnes qui en ont le plus besoin, quelle que soit « leur capacité ou leur volonté de payer ». De plus, si le coût d'un tel programme est prohibitif, la valeur des avantages pourrait être taxable afin que l'apport des patients soit directement lié à la capacité de payer, sous forme de taxe supplémentaire. La couverture limitée du RSG au Canada est inquiétante. Les besoins liés au RSG ne sont pas respectés chez les patients atteints de la maladie cœliaque au Canada. Le milieu canadien de la médecine et l'Association canadienne de la maladie coliaque devront consentir plus d'efforts pour déterminer des moyens d'améliorer l'attribution des ressources dans le secteur de la maladie cœliaque.
Celiac disease (CD) is a chronic, small intestinal, immunemediated disorder affecting $1 \%$ of the North American population (1), with an increasing incidence in the past 40 years (2). Studies outside of North America have revealed that CD is common, occurring in Caucasian as well as non-Caucasian populations. In Canada, serological screening has estimated that approximately 350,000 Canadians have this condition $(3,4)$.

The disease is precipitated by the ingestion of gluten in individuals with genetic predisposition conferred by the presence of human leukocyte antigen-DQ2 or -DQ8. The only currently available treatment is the lifelong avoidance of gluten $(5,6)$. The principal sources of dietary gluten are wheat, barley and rye. The term 'gluten-free' indicates a diet that contains gluten at such a low level as to be considered harmless for celiac patients (7). There are two types of gluten-free foods available for those requiring a gluten-free diet (GFD): naturally gluten-free foods, which are foods that naturally do not contain gluten (eg, fruits, vegetables, meat, eggs, rice and potatoes); and gluten-free substitutes, which are food products that have been manufactured as alternatives to gluten-containing counterparts, such as bread and pasta. Quality and palatability of gluten-free substitutes vary significantly among brands and products.

Compliance with a GFD will result in resolution of symptoms and repair of the intestinal damage over time in most individuals with CD (7). However, failure to adhere to the GFD carries risk of adverse

${ }^{1}$ Department of Medicine, Farncombe Family Digestive Research Institute, McMaster University; ${ }^{2}$ Kaizen Accounting, Hamilton, Ontario; ${ }^{3}$ Hospital de Gastroenterología Dr C B Udaondo, Buenos Aires, Argentina; ${ }^{4}$ Centre for Health Economics and Policy Analysis, Department of Clinical

Epidemiology $\mathcal{E}$ Biostatistics, McMaster University, Hamilton, Ontario

Correspondence: Dr Premysl Bercik, 1280 Main Street West, McMaster University Medical Centre, 3N9, Hamilton, Ontario L8S 4K1.

Telephone 905-525-9140 ext 22212,fax 905-522-3454, e-mail bercikp@mcmaster.ca

Received for publication November 20, 2014. Accepted December 5, 2014 
TABLE 1

Example tax deduction system for a single gluten-free (GF) item and calculations for tax deduction

Example of a single item

1. Item: bread.

2. Number of items purchased: 52

3. Average cost of non-GF product: $\$ 3.49$

4. Average cost of GF product: $\$ 6.99$

5. Incremental cost (line 4 minus line 3): $\$ 6.99-\$ 3.49=\$ 3.50$

6. Amount to claim (line 5 multiplied by line 2 ): $\$ 3.50 \times 52=\$ 182.00$

Example of the calculations for tax deduction

\begin{tabular}{|c|c|c|c|c|c|c|}
\hline Item (Company, Country) & Items purchased, $\mathbf{n}$ & $\begin{array}{c}\text { Non-GF food cost } \\
\text { (comparable brand), } \$\end{array}$ & $\begin{array}{l}\text { Non-GF food } \\
\text { amount, } g\end{array}$ & $\begin{array}{l}\text { GF food } \\
\text { cost, } \$\end{array}$ & $\begin{array}{c}\text { GF food } \\
\text { amount, } g\end{array}$ & Cost difference, $\$$ \\
\hline Polenta crisps (Dendy \& Co, Canada) & 1 & 2.50 & 400 & 4.99 & 120 & 4.24 \\
\hline Chicken nuggets (lan's Natural Foods, USA) & 10 & 6.00 & 870 & 7.99 & 224 & 64.45 \\
\hline Cereal (Nature's Path, USA) & 22 & 3.49 & 500 & 4.79 & 325 & 55.47 \\
\hline GF Pantry cookies (Glutino, USA) & 1 & 3.79 & & 5.99 & 340 & 2.20 \\
\hline Pancake mix (Kinnikinnick Foods, Canada) & 4 & 3.00 & 905 & 5.49 & 454 & 15.94 \\
\hline Bread (Udi's, USA) & 18 & 2.50 & 600 & 5.99 & 340 & 82.32 \\
\hline Croutons (PaneRiso Foods, Canada) & 1 & 2.89 & & 4.99 & 175 & 2.10 \\
\hline Mini brownies (President's Choice, Canada) & 1 & 2.69 & & 5.99 & 280 & 3.30 \\
\hline Chocolate muffins (President's Choice, Canada) & 2 & 3.99 & & 5.99 & 372 & 4.00 \\
\hline Blueberry muffins (President's Choice, Canada) & 1 & 3.99 & & 5.99 & 372 & 2.00 \\
\hline $\begin{array}{l}\text { Betty Crocker GF cake mix (General Mills, } \\
\text { Canada) }\end{array}$ & 3 & 3.99 & & 5.99 & 425 & 6.00 \\
\hline Macaroni \& cheese (Annie's, USA) & 5 & 1.50 & & 4.29 & 170 & 13.95 \\
\hline Candy bar (Glutino, USA) & 2 & 2.79 & & 4.49 & 125 & 3.40 \\
\hline Hotdog buns (Udi's, USA) & 1 & 2.99 & 672 & 6.79 & 365 & 5.17 \\
\hline Spaghetti (Catelli, USA) & 4 & 1.67 & 900 & 2.99 & 340 & 9.43 \\
\hline Genius bread (Glutino, USA) & 3 & 2.50 & & 5.49 & 395 & 24.60 \\
\hline Granola bar (Bakery on Main) & 5 & 2.50 & & 4.70 & 170 & 11.00 \\
\hline Hamburger buns (Udi's, USA) & 3 & 2.99 & 672 & 5.79 & 295 & 13.43 \\
\hline Donuts (Glutino, USA) & 1 & 2.49 & & 4.44 & 340 & 1.95 \\
\hline Pretzels (Glutino, USA) & 3 & 3.50 & & 8.99 & 400 & 16.47 \\
\hline Pizza (Sarafina, Canada) & 1 & 4.99 & 900 & 9.99 & 355 & 8.00 \\
\hline Rice crisps (President's Choice, Canada) & 17 & 1.50 & & 3.29 & 100 & 30.43 \\
\hline Banana loaf (President's Choice, Canada) & 4 & 3.49 & & 5.99 & 454 & 10.00 \\
\hline English muffins (Glutino, USA) & 3 & 2.99 & & 5.99 & 480 & 9.00 \\
\hline GF Pantry pizza mix (Glutino, USA) & 5 & 3.29 & & 5.99 & 624 & 13.50 \\
\hline Total & & & & & & 412.35 \\
\hline
\end{tabular}

health consequences in celiac patients. These include increased risk for incidence of bone fractures (8-11), malignancies (small bowel adenocarcinoma, esophageal cancer, B cell and T cell non-Hodgkin lymphomas) and increased mortality (12-15). Furthermore, women with CD have an increased risk for infertility, spontaneous abortions, preterm deliveries and delivery of low-birth-weight infants (7). Evidence suggests the risk of complications is reduced in those who strictly adhere to a GFD (12-22).

Although products safe for consumption by celiac patients are labelled and certified as 'gluten-free', following a GFD can be cumbersome. Strict avoidance of gluten is challenging because of many hidden sources of gluten in processed food products, cosmetics and drugs. Moreover, celiac patients find that a GFD is difficult to follow, socially inconvenient $(7,23)$ and more expensive than a regular diet. Glutenfree products can cost more than twice as much as 'regular' wheatbased products $(24,25)$, with added extra costs such as shipping for some gluten-free specialty items. This increases the challenge for the celiac patient to comply with a GFD. To improve compliance among celiac patients, many jurisdictions provide programs to help meet the extra costs attached to living on a GFD. However, there is wide variation in the content and scope of the different approaches adopted. The objective of the present review was to assess how these approaches compare in terms of the expected level and distribution of impact on patient uptake and compliance with a GFD.

\section{TAX REDUCTION FOR COSTS OF GLUTEN-FREE PRODUCTS}

In Canada, celiac patients certified by a medical practitioner may claim the incremental cost associated with the purchase of gluten-free products compared with the cost of corresponding non-gluten-free products, as a medical expense to be deducted from their personal income before calculation of income tax (26). Table 1 shows an example of the calculation of a deduction. No allowance is made for the costs associated with finding (transport) and receiving (shipping) gluten-free products.

In the United States, if a taxpayer can establish the medical purpose of the diet, such as through a physician's diagnosis, the incremental cost of the diet is a medical care expense under section 213 (27-29). Rulings by the Internal Revenue Service suggest that if the total medical expenses for the year exceed $7.5 \%$ of the individual's adjusted gross income, then the incremental cost of the GFD, including the total cost of items that would not be purchased at all if the individual did not have CD, as well as other expenses related to transportation or shipping costs, are deductible $(27,28)$. 
TABLE 2

Estimated cost of gluten-free (GF) products in Argentina currency (AR\$) and Canadian currency (CAD\$) compared with regular wheat-containing products, and marginal cost for celiac patients

\begin{tabular}{|c|c|c|c|c|c|c|}
\hline \multirow[b]{2}{*}{ Product } & \multirow[b]{2}{*}{ Amount } & \multicolumn{4}{|c|}{ Estimated cost } & \multirow{2}{*}{$\begin{array}{c}\text { Marginal cost: } \\
\text { GF - non-GF, CAD\$ }\end{array}$} \\
\hline & & GF, AR\$* & GF, CAD\$ $\$^{\dagger}$ & Non-GF, AR\$* & Non-GF, CAD\$ ${ }^{\dagger}$ & \\
\hline Oil & $1 \mathrm{~L}$ & 17.00 & 3.40 & 5.98 & 1.19 & 2.21 \\
\hline Corn starch & $1.5 \mathrm{~kg}$ & 49.29 & 3.60 & 28.89 & 5.77 & 2.17 \\
\hline Cacao powder & $800 \mathrm{~g}$ & 70.00 & 14.00 & 23.95 & 4.79 & 9.21 \\
\hline Quince jam & $1 \mathrm{~kg}$ & 30.00 & 6.00 & 19.90 & 3.98 & 2.02 \\
\hline Rice flour & $1 \mathrm{~kg}$ & 30.00 & 6.00 & 30.00 & 6.00 & 0.00 \\
\hline Baking powder & $400 \mathrm{~g}$ & 35.00 & 7.00 & 6.64 & 1.32 & 5.67 \\
\hline Rice & $1 \mathrm{~kg}$ & 10.00 & 2.00 & 7.77 & 1.55 & 0.45 \\
\hline Bread mix & $500 \mathrm{~g}$ & 20.00 & 4.00 & 20.00 & 4.00 & 0.00 \\
\hline Total & & 322.00 & 64.40 & 213.19 & 42.65 & 21.75 \\
\hline
\end{tabular}

${ }^{*}$ Least expensive price obtained from COTO, Argentina <http://www.cotodigital.com.ar/Home.asp >; ${ }^{\dagger}$ Currency exchange: 1 CAD $\$=5$ AR $\$$ as for official exchange in 2010

If the total medical expenses are $<7.5 \%$ of the adjusted gross income, then Flexible Spending Account (30) provisions can be used to pay for the incremental cost of the GFD (including related shipping expenses), providing a similar 'tax break' for these costs. Finally, for low-income families, the food stamp program (31) may help them buy the food they need to remain healthy.

The uses of tax offsets, or tax expenditures as they are referred to in public finance, have several features that may limit the impact of the approach on uptake and compliance with a GFD among celiac patients. First, the tax offset takes the form of a reimbursement (tax refund or reduction in taxes to be paid) of a cost previously incurred. Hence, the program does not help celiac patients meet the incremental cost of the GFD, it simply provides some future refund of that cost. The household resources, from which the incremental cost of the GFD must be paid, remain the same. In the case where the GFD is not affordable, the prospect of a future tax refund to cover part of this cost is of no help. Second, the value of the tax offset is directly related to the celiac patient's marginal rate of tax. If the patient does not have sufficient income to pay income tax, there is no tax refund to be claimed. In contrast, someone paying tax at a marginal rate of $50 \%$ will receive a tax refund equal to $50 \%$ of the incremental cost of the GFD. Therefore, although we may expect low-income patients with $\mathrm{CD}$ to have greater difficulty covering a GFD, the level of support for meeting these costs is greatest among higher-income celiac patients, for whom affordability of the GFD is less likely to be a problem. As a result, the impact of tax deductions on GFD uptake is unlikely to be substantial, even if celiac patients participate in the program claiming the deductions against tax that they qualify for. However, the inconvenience of retaining receipts for gluten-free products along with receipts for gluten-containing foods to determine the incremental cost of the GFD, together with problems arising from differences in packaged quantities and serving sizes between gluten-free and gluten-based brands, means that uptake of the tax deduction may be less than universal among celiac patients.

From a government perspective, the approach is relatively low cost, because it is delivered and administered through an existing bureaucracy (the taxation system) and, as indicated above, is unlikely to have a $100 \%$ uptake among eligible individuals. It also represents, at best, only partial reimbursement of the incremental costs of GFD and, in the case of non-income tax payers, no reimbursement whatsoever. However, there will likely be additional costs due to audit and enforcement to avoid claims based on inflated incremental costs associated with comparing high-cost varieties of gluten-free products with low-cost varieties of gluten-based products. Difficulties on the calculation of real incremental cost of gluten-free products are, in part, due to differences in package amounts and serving sizes of different brands.

The advantage of this system is that it constitutes the least costly approach compared with other options. The government does not need to deal with specific intermediaries because the procedures are performed during the regular tax claiming process.

\section{MONEY PROVISION OR CASH TRANSFER}

Some countries provide money to celiac patients. For example, in Argentina, a law passed in 2009 (32) provides celiac patients with the equivalent to $\$ 50$ per month to offset the incremental costs of a GFD. Celiac patients are not required to provide proof of purchase of glutenfree food. Italy provides a monthly allowance to offset the incremental cost of gluten-free foods for those with CD. The allowance varies by region in accordance with local regulations and ranges from $\$ 184$ to $\$ 200$ per month. Gluten-free foods eligible to be purchased with the stipend are found on a list maintained by the Ministry of Health (33), which has established standards for a product being designated gluten free. In addition, CD patients receive extra time off work to offset the time taken to find and prepare gluten-free food. Furthermore, schools, hospitals and other public facilities must provide gluten-free food options.

This approach is more generous than the tax offset program because it provides upfront support of the incremental costs of the GFD equally to all celiac patients and, hence, it is more costly to the government. However, the GFD allowance is not 'earmarked' for spending only on gluten-free products. Celiac patients could, therefore, choose to simply reduce any existing spending on gluten-free products, effectively using the allowance in part or entirely on nongluten-free products. As a policy aimed at increasing uptake and compliance with a GFD, any such substitution of allowance for existing GFD spending would represent an unintended 'leakage' of funds to other products. Moreover, if allowances are to be universal among all celiac patients, it implies that those allowances allocated to existing compliers have no impact on compliance. Instead, they simply transfer funds from taxpayers to compliant celiac patients. If compliance is correlated positively with patient income, then these allowances could be 'clawed back' by making them taxable. Those patients who already have the capacity to purchase GFD products would receive less than the full incremental cost of the GFD after payment of tax $(34,35)$. Also, in some societies, administering a program of cash transfers involves risks of loss while transporting and distributing cash (34). Concern is being raised in countries such as Italy, where this system may impose a significant burden in terms of cost to the health care system, as opposed to the tax and benefits system.

\section{DIRECT FOOD PROVISION}

Some provinces in Argentina (36,37) and Spain (38) provide celiac patients with a monthly supply of specific gluten-free food. An example of a monthly food supply for CD patients in Argentina is shown in Table 2. The amount of food provided is based on the average consumption of gluten-free products per person (36). The program 
is means tested to concentrate resources on celiac patients who are least able to meet the incremental cost of GFD. However, direct distribution and provision of food is costly, as is the administration and enforcement of means testing. The impact on uptake and compliance with a GFD is expected to exceed that of the other programs because it restricts patients from using program benefits for non-GFD products. In principle, patients could exchange gluten-free foods for other products, but there would appear to be a limited market for such exchange if all celiac patients receive the food allowance. In the presence of means testing, however, opportunities may exist for those patients who do not qualify for the food allowance because of their income level to exchange money or other products with those receiving the food allowance at prices below the market price of GFD.

Furthermore, testing for CD leads to program resources being targeted on those patients most at risk of not complying with the diet for affordability reasons, further enhancing the likely impact of the program on total uptake and compliance.

\section{Price subsidy}

In many countries, including New Zealand, the Republic of Ireland and the United Kingdom, gluten-free food is prescribed by physicians and, hence, the cost of the food is covered under the same arrangements as prescribed drugs. This usually involves some form of partial or total subsidy or fixed prepayment provision.

In New Zealand, specific gluten-free products are partially subsidized by the government under the Pharmac Part-Subsidy program for pharmaceuticals (39). Once the physician has submitted a form with the $\mathrm{CD}$ diagnosis confirmed by a duodenal biopsy, the patient can purchase gluten-free products at one-half of the retail price in a regular store, the other one-half being funded by the program. Examples of products and pricing available under the Pharmac part-subsidy in New Zealand are shown in Table 3 (39). In the Republic of Ireland, glutenfree foods fall under a Drug Payment Scheme, which sets a maximum monthly out-of-pocket expenditure that an individual or family would pay for prescription drugs, other medicine and certain appliances (as of December 31, 2012, that was $€ 144$ [approximately \$194]). Typically, the general practitioner (GP) would prescribe specific gluten-free foods from a general medical services list that includes items such as bread, rolls, bread mixes and flour, pasta, breakfast cereals, pizza bases and baking powder. Eligible patients collect the prescribed gluten-free foods at the pharmacy. The United Kingdom also offers gluten-free foods under prescription using an approved list determined by the Advisory Committee on Borderline Substances (available in Coeliac UK's online Food and Drink Directory <www.coeliac.org.uk/glutenfree-diet-and-lifestyle/food-shopping/food-and-drink-directory/>).

The quantity of gluten-free food prescribed is largely based on a recommended number of units per month. For example, $400 \mathrm{~g}$ of glutenfree baguettes and $250 \mathrm{~g}$ gluten-free pasta would each count as one unit. The recommended number of allowable units varies according to age, sex and other factors, such as pregnancy or breastfeeding. The celiac society in the United Kingdom has established a strong position on items that can be prescribed under the plan, restricting the list to essential healthy products while excluding food considered not essentially 'healthy' such as gluten-free cake mixes and desserts. Of course, celiac patients can still purchase these items out of pocket at the store. Each item of prescribed gluten-free product carries a fixed prescription fee of $£ 7.65$. Elderly patients, children and people on welfare benefits are exempt from prescription charges. In addition, because a full list of prescribed gluten-free items would become expensive (eg, bread, pizza base, pasta and crackers would carry a charge for four items or approximately £30), fixed-price prepayment certificates can be purchased for periods of three months ( $£ 29.10)$ or one year $(£ 104)$.

This approach has the potential to make the GFD more affordable to celiac patients provided they qualify for fee exemptions or purchase a prepayment certificate. However, the price of gluten-free products purchased at retail stores may be less than the per-item prescription charge (which is set annually in relation to National Health Service

\section{TABLE 3}

Example of gluten-free products coverage through a subsidy system in New Zealand

\begin{tabular}{|c|c|c|c|}
\hline $\begin{array}{l}\text { Items available on special foods } \\
\text { schedule part subsidized }\end{array}$ & Size & $\begin{array}{c}\text { Cost, } \\
\text { including } \\
\text { GST, \$ }\end{array}$ & $\begin{array}{l}\text { Approximate } \\
\text { retail, } \$\end{array}$ \\
\hline Orgran* corn \& vegetable spirals & $250 \mathrm{~g}$ & 2.07 & 4.90 \\
\hline Orgran rice \& millet spirals & $250 \mathrm{~g}$ & 2.30 & 5.20 \\
\hline Orgran buckwheat spirals & $250 \mathrm{~g}$ & 2.30 & 5.20 \\
\hline Orgran vegetable \& rice spirals & $250 \mathrm{~g}$ & 2.07 & 4.90 \\
\hline Orgran rice \& maize spirals & $250 \mathrm{~g}$ & 2.07 & 4.90 \\
\hline Orgran corn and vegetable shells & $250 \mathrm{~g}$ & 2.07 & 4.90 \\
\hline Orgran rice \& corn spaghetti/noodles & $250 \mathrm{~g}$ & 2.07 & 5.20 \\
\hline Orgran rice \& corn lasagne sheets & $375 \mathrm{~g}$ & 2.07 & 7.00 \\
\hline Orgran rice \& corn penne & $200 \mathrm{~g}$ & 3.79 & 4.90 \\
\hline Orgran rice \& corn macaroni & $250 \mathrm{~g}$ & 2.07 & 4.90 \\
\hline Orgran Italian-style spaghetti, long & $220 \mathrm{~g}$ & 2.07 & 5.20 \\
\hline Bakels $^{\dagger}$ health bread mix & $1 \mathrm{~kg}$ & 4.65 & 13.30 \\
\hline Bakels low gluten bread mix & $1 \mathrm{~kg}$ & 4.83 & 12.20 \\
\hline Horleys $^{\dagger}$ flour & $2 \mathrm{~kg}$ & 16.10 & 30.40 \\
\hline Horleys bread mix & $1 \mathrm{~kg}$ & 9.71 & 18.50 \\
\hline Simple $^{\dagger}$ baking mix & $1 \mathrm{~kg}$ & 5.10 & 10.90 \\
\hline
\end{tabular}

${ }^{*}$ Australia; ${ }^{\dagger}$ New Zealand. GST Goods and services tax

[NHS] plans as opposed to the cost of prescribed products). But this price difference is likely to be less than the subsidization arising from use of prepayment certificates and, hence, these arrangements will reduce the cost of the GFD. Whether this increases uptake and compliance with a GFD will also depend on the additional costs on individuals of having to attend the doctor's office for a prescription and the pharmacy for dispensation of the prescribed items. Patients may prefer to go directly to the grocery store if they can afford the nonsubsidized retail price, but people with low income have no other option. Collecting food from the pharmacy may involve social stigma for the patient while some doctors complain that by prescribing food items they risk resembling a 'grocery store' (40). Finally, the system involves coordination of several different providers from several intermediaries (GPs, pharmacists, third-party payers), which increases the administration costs of the program to the government.

In Switzerland, as well as under the NHS in Northern Ireland, Scotland and Wales, gluten-free products are provided through physician prescription without any patient charge. The principle is the same as in New Zealand and under the NHS in England; however, the level of subsidy is $100 \%$. Recently, some changes have been introduced in Scotland with a Gluten-Free Food Additional Pharmaceutical Service being introduced on a limited period trial basis (33). The monthly prescription will no longer be provided by the GP, but from the pharmacist following referral from a GP or dietician stating the diagnosis and number of units of gluten-free food required per month. Pharmacists are responsible for assisting patients in selecting the most appropriate gluten-free foods, and agreeing with patients on the frequency of collection (41).

Under the scheme, the choice of gluten-free foods should be limited to a local formulary produced by NHS boards: "to optimise value for money and clinical effectiveness" (40). The scheme will be reviewed for its impact on "the clinical benefit for the patients concerned and cost effectiveness for NHS Scotland" $(40,41)$ in comparison with the previous arrangements. Gluten-free food remains free to patients with a physician's prescription but access to the products is improved by providing the patient with direct access to the supplier (pharmacist) following an initial physician diagnosis. Funding for the new program is based on two elements. A fixed tariff of $£ 125$ per month is allocated to pharmacists for each eligible celiac patient, with an additional tariff based on the percentage corresponding to chronic medication service (41). 
TABLE 4

Differences among available systems for gluten-free product coverage

\begin{tabular}{|c|c|c|c|c|c|c|}
\hline & Tax deduction & Cash transfer & Food provision & Prescription & Subsidy & No coverage \\
\hline Premium coverage & Partial & Total & Total & Partial & Partial/total & None \\
\hline $\begin{array}{l}\text { Example of } \\
\text { countries with } \\
\text { this system }\end{array}$ & $\begin{array}{l}\text { Canada, United } \\
\text { States, Netherlands, } \\
\text { Portugal }\end{array}$ & $\begin{array}{l}\text { Italy, Argentina, } \\
\text { Uruguay, Finland, } \\
\text { Greece, France, } \\
\text { Norway, Belgium, } \\
\text { Slovenia (child) }\end{array}$ & $\begin{array}{l}\text { Some provinces in } \\
\text { Argentina and Spain }\end{array}$ & $\begin{array}{l}\text { New Zealand, } \\
\text { Republic of Ireland, } \\
\text { United Kingdom }\end{array}$ & $\begin{array}{l}\text { Northern Ireland, } \\
\text { Scotland, Czech } \\
\text { Republic, Wales }\end{array}$ & $\begin{array}{l}\text { Mexico, Spain (some } \\
\text { provinces), } \\
\text { Germany, Slovenia } \\
\text { (adults) }\end{array}$ \\
\hline $\begin{array}{l}\text { Approximate } \\
\text { amount } \\
\text { (USD\$/month) }\end{array}$ & $\begin{array}{l}\text { Variable, depending } \\
\text { on income }\end{array}$ & 50.00 to 327.00 & 60.00 & Maximum of 194.00 & Maximum of 203.63 & 0.00 \\
\hline Advantages & $\begin{array}{l}\text { Low cost for } \\
\text { government. No new } \\
\text { intermediaries }\end{array}$ & $\begin{array}{l}\text { Convenient for } \\
\text { patients. Less costly } \\
\text { for government. } \\
\text { Requires fewer } \\
\text { intermediaries }\end{array}$ & $\begin{array}{l}\text { Direct provision of } \\
\text { treatment. Greater } \\
\text { compliance } \\
\text { expected }\end{array}$ & $\begin{array}{l}\text { Less costly treatment } \\
\text { with more } \\
\text { purchasing power } \\
\text { for other goods }\end{array}$ & $\begin{array}{l}\text { Full coverage of treat- } \\
\text { ment. Provides more } \\
\text { purchasing power to } \\
\text { patients }\end{array}$ & $\begin{array}{l}\text { No cost for } \\
\text { government }\end{array}$ \\
\hline Disadvantages & $\begin{array}{l}\text { Inconvenient for peo- } \\
\text { ple with low income. } \\
\text { Need to save } \\
\text { receipts and calcula- } \\
\text { tions. Non- } \\
\text { refundable tax credit } \\
\text { subject to income } \\
\text { declared; imperfect } \\
\text { coverage, depend- } \\
\text { ing on product } \\
\text { brand. Possible } \\
\text { abuse by tax payers }\end{array}$ & $\begin{array}{l}\text { If not controlled, could } \\
\text { lead to other } \\
\text { expenditures and } \\
\text { consequently low } \\
\text { treatment } \\
\text { compliance. } \\
\text { Risk of cash misuse }\end{array}$ & $\begin{array}{l}\text { Expensive for govern- } \\
\text { ment. Possible loss } \\
\text { of quality in products } \\
\text { provided (cheapest } \\
\text { option) }\end{array}$ & $\begin{array}{l}\text { Inconvenient for } \\
\text { patients in getting } \\
\text { the prescription from } \\
\text { GP. Inconvenient for } \\
\text { GP who feels like a } \\
\text { 'grocery store'. } \\
\text { Several } \\
\text { intermediaries with } \\
\text { increased marginal } \\
\text { cost for government }\end{array}$ & $\begin{array}{l}\text { Inconvenient for } \\
\text { patients in getting } \\
\text { the prescription from } \\
\text { GP. Inconvenient for } \\
\text { GP who feels like a } \\
\text { 'grocery store'. } \\
\text { Several } \\
\text { intermediaries with } \\
\text { increased marginal } \\
\text { cost for government }\end{array}$ & $\begin{array}{l}\text { No coverage of } \\
\text { treatment for } \\
\text { patients, who need } \\
\text { to face the extra } \\
\text { costs related to } \\
\text { gluten-free diet }\end{array}$ \\
\hline
\end{tabular}

GP General practitioner

No coverage for gluten-free products

In many jurisdictions, including Mexico and most provinces in Spain, no financial support is provided for celiac patients' purchases of GFD. The celiac community in Mexico is currently actively campaigning for financial support from government to contribute to the extra costs of GFD (42).

A summary of main characteristics, advantages and disadvantages of each program is shown in Table 4.

\section{HOW SOCIETY AND GOVERNMENT BENEFIT FROM EACH SYSTEM}

Given that resources for health care are limited, governments must consider the impact of the different approaches on uptake and compliance with a GFD and, hence, patient outcomes, as well as any additional consequences for the health care system arising from changes in uptake and compliance.

Doing nothing is always an option for decision-makers and it may be attractive for those responsible for expenditure control. However, the option is likely to result in low levels of uptake and compliance and lead to additional demands on the health care system as celiac patients present with health problems. Compared with 'doing nothing', income support programs are aimed at providing more resources to patients for them to allocate however they like. They make people better off and, in economic terms, this generates an 'income effect' resulting in the individual being able to purchase more of any good or service than he previously purchased. Gluten-free products are not particularly favoured under this policy, because the price of gluten-free products remains the same relative to all other products. Hence, from an economics perspective, this policy does not make gluten-free products any more attractive than without the income supplement and the individual is able to spend the additional income in accordance with his relative preferences among all goods and services.

In contrast, price subsidies make individuals feel better off, because the amount of the subsidized gluten-free product purchased by the individual now costs less and so 'savings' accrue from this price reduction to spend on either more gluten-free foods or on other items. As with the income supplement, this is an 'income effect'. However, the subsidy has now made gluten-free products more attractive to patients because they are now less costly than others items in relative terms. The amount of other items you now must forgo to afford any particular gluten-free product has fallen. Thus, there is a 'substitution effect', which is an additional incentive to spend the 'savings' from the price reduction on gluten-free foods.

Investing resources in a price subsidy policy would be expected to have a greater impact on uptake and compliance than using the same resources for an income enhancement program. Similarly, price subsidies may be more effective than income enhancement in improving the distribution of uptake and compliance among the celiac disease population. Under income supplements, patients from poorer households may face greater immediate priorities for household spending such as accommodation, clothing and food for other family members whereas among better-off groups, the income supplements may contribute more to discretionary expenditures and, hence, may be more likely to be allocated to GFD. However, under price subsidies, the impact on uptake would be expected to produce more equitable distributions if individuals from poorer households are more sensitive and responsive to price changes in particular commodities because the savings made represent a much larger proportion of their household budget.

These expected outcomes are conditional on having few if any barriers to access to the programs. Complex or inconvenient methods of taking advantage of subsidies may mitigate the impact of those subsidies on affordability and, hence, adherence to a GFD. Similarly, if the methods used for direct provision stigmatize patients, the policy may be unacceptable to some potential beneficiaries and reduce the impact on uptake.

\section{DISCUSSION AND CONCLUSION}

The purpose of the present analysis was to review the different systems available to support GFD coverage as a treatment for CD patients. The review showed that the systems in place exhibit particular advantages and disadvantages in relation to promoting uptake and compliance 
with GFD. The analysis described in the present article demonstrated that the tax offsets for GFD creates inequity because they help least those in most need. If we define needs in terms of marginal capacity to benefit from health care, the health maximization model has the principle that those in equal needs should have equal access to service (43).

There is strong evidence that poor compliance with the GFD in $\mathrm{CD}$ patients places patients at risk for severe complications (7). For this reason, support for this treatment for those who are most in need (ie, those least able to meet the incremental cost of the GFD) is important. Increased demand of GFD in celiac patients is usually accompanied by better treatment compliance $(7,44-46)$. Increasing coverage among those in need is likely to be associated with greater compliance and, hence, a decrease in complications due to the disease, which mitigates the cost of the program. A balanced approach would consist of subsidizing gluten-free products through controlled vouchers or direct food provision to those who most need it, independent of ability or willingness to pay. Moreover, if the cost of such a program is prohibitive, the value of the benefits could be made taxable to ensure that any patient contribution (in terms of additional taxation) is directly related to ability to pay.

We may question whether the GFD should be covered at all, given that a natural diet of fruits and vegetables is gluten free. However, individuals with low socioeconomic status consume a diet that heavily relies on wheat-containing products and that is low in fruit and

\section{REFERENCES}

1. Pulido O, Zarkadas M, Dubois S, et al. Clinical features and symptoms recovery on a gluten-free diet in Canadian adults with celiac disease. Can J Gastroenterol 2013;27:449-53.

2. Ludvigsson JF, Rubio-Tapia A, van Dyke CT, et al. Increasing incidence of celiac disease in a North American population. Am J Gastroenterol 2013;108:818-24.

3. Fasano A, Berti I, Gerarduzi T, et al. Prevalence of celiac disease in at-risk and not-at-risk groups in the US: A large multicenter study. Arch Intern Med 2003;163:286-92.

4. Statistics Canada. Canada' total population estimates 2013. <www.statcan.gc.ca/daily-quotidien/130926/dq130926a-eng.htm> (Accessed March 2014).

5. Zarkadas M, Case S. Celiac diasease and the gluten free diet: An overview. Topics Clin Nutr 2005;20:127-38.

6. Rashtak S, Murray JA. Celiac disease: New approaches to therapy. Alim Pharmacol Ther 2012;35:768-81.

7. Rubio-Tapia A, Hill I, Kelly CP, et al. ACG clinical guidelines: Diagnosis and management of celiac disease. Am J Gastroenterol 2013;108:656-76.

8. Akobeng AK, Thomas AG. Systematic review: Tolerable amount of gluten for people with coeliac disease. Aliment Pharmacol Ther 2008;27:1044-52.

9. Lucendo AJ, García-Manzanares A. Bone mineral density in adult coeliac disease: An updated review. Rev Esp Enferm Dig 2013;105:154-62.

10. Pinto-Sánchez MI, Mohaidle A, Baistrocchi A, et al. Risk of fracture in celiac disease: Gender, dietary compliance, or both? World J Gastroenterol 2011;17:3035-42

11. Olmos M, Antelo M, Vazquez H, et al. Systematic review and metaanalysis of observational studies on the prevalence of fractures in coeliac disease. Dig Liver Dis 2008;40:46-53.

12. Ludvigsson JF. Mortality and malignancy in celiac disease. Gastrointest Endosc Clin N Am 2012;22:705-22.

13. West J, Logan RF, Smith CJ, et al. Malignancy and mortality in people with coeliac disease: Population based cohort study. BMJ 2004:329:716-9.

14. Askling J, Linet M, Gridley G, et al. Cancer incidence in a population based cohort of individuals hospitalized with celiac disease or dermatitis herpetiformis. Gastroenterology 2002;123:1428-35

15. Corrao G, Corazza GR, Bagnardi V, et al. Mortality in patients with coeliac disease and their relatives: A cohort study. Lancet 2001;358:356-61.

16. Sategna-Guidetti C, Grosso SB, Grosso S, et al. The effects of 1 -year gluten withdrawal on bone mass, bone metabolism and vegetables $(47,48)$. Programs could, therefore, be developed with the objective to generate changes in dietary habits in the long term, alongside immediate policies to promote uptake and compliance.

Economic evaluations of alternative approaches are needed to provide an empirical base for policy formulation and decision making, with the ultimate objective of achieving maximum uptake and compliance from whatever resources are committed to support celiac patients. International comparisons provide insights about alternative approaches and different contexts with countries learning from systems implemented elsewhere. This helps individual jurisdictions to assess their own policy options (49).

Finally, the limited coverage of GFD in Canada is concerning. This could reflect a lack of interest and understanding of the disease burden by governments. More efforts are required by the Canadian medical community and the Canadian Celiac Society to act as agents in identifying ways of improving resource allocation in celiac disease. There is definitely an unmet need for GFD among celiac patients in Canada.

DICLOSURES: The authors have no financial disclosures or conflicts of interest to declare.

FUNDING: MIPS received a CIHR/CAG Post-Doctoral Fellowship for the period 2014-2016. PB received the Hamilton Health Sciences Research Early Career Award. nutritional status in newly-diagnosed adult coeliac disease patients. Aliment Pharmacol Ther 2000;14:35-43.

17. Valdimarsson T, Lofman O, Toss G, et al. Reversal of osteopenia with diet in adult coeliac disease. Gut 1996;38:322-7.

18. Choi JM, Lebwohl B, Wang J, et al. Increased prevalence of celiac disease in patients with unexplained infertility in the United States. J Reprod Med 2011;56:199-203

19. Ciacci C, Cirillo M, Auriemma G, et al. Celiac disease and pregnancy outcome. Am J Gastroenterol 1996;91:718-22.

20. Norgard B, Fonager K, Sorensen HT, et al. Birth outcomes of women with celiac disease: A nationwide historical cohort study. Am J Gastroenterol 1999;94:2435-40.

21. Ludvigsson JF, Montgomery SM, Ekbom A. Celiac disease and risk of adverse fetal outcome: A population-based cohort study. Gastroenterology 2005;129:454-63.

22. Khashan AS, Henriksen TB, Mortensen PB, et al. The impact of maternal celiac disease on birth weight and preterm birth: A Danish population based cohort study. Hum Reprod 2010;25:528-34.

23. Verrill L, Zhang Y, Kane R. Food label usage and reported difficulty with following a gluten-free diet among individuals in the USA with coeliac disease and those with noncoeliac gluten sensitivity. J Hum Nutr Diet 2013;26:479-87.

24. Lee A, Ng DL, Zivin J, Green P. Economic burden of a gluten-free diet. J Hum Nutr Diet 2007;20:423-30.

25. Tennyson CA, Simpson S, Lebwohl B, et al. Interest in medical therapy for celiac disease. Therap Adv Gastroenterol 2013;6:358-64.

26. Canada Revenue Agency Website: <www.cra-arc.gc.ca/tx/ndvdls/ tpcs/ncm-tx/rtrn/cmpltng/ddctns/lns300-350/330/clc-eng.html> (Accessed March 2014).

27. US Internal Revenue Service. Medical and Dental Expenses <www.irs.gov/taxtopics/tc502.html> (Accessed November 19, 2014).

28. Medical and Dental Expenses (Including the Health coverage tax credit) Publication 502. Department of the Treasury Internal Revenue Service. <www.irs.gov/pub/irs-pdf/p502.pdf> (Accessed November 19, 2014).

29. Gluten free federal tax deduction. Celiac Sprue Association. <www.csaceliacs.info/tax_deductions.jsp> (Accessed March 2014).

30. Flexible spending accounts. Office of Personnel management U.S. <www.opm.gov/healthcare-insurance/flexible-spending-accounts/> (Accessed March 2014).

31. Supplemental Nutrition Assistance Program (SNAP). US Department of Agriculture, Food and Nutrition service. <www.fns. usda.gov/snap/supplemental-nutrition-assistance-program-snap> (Accessed March 2014).

32. La ley celiaca Argentina. <www.ley-celiaca.com.ar/> (Accessed March 2014) 
33. Ministerio della salute -Senza glutine. Regolamento 41/2009<www. salute.gov.it/portale/temi/p2_6.jsp?lingua $=$ italiano\& $i d=979 \&$ area $=A$ limenti\%20particolari\%20e\%20integratori\&menu=dietetici $>$ (Accessed March 2014).

34. Cash transfer in programming emergencies. <www.unscn.org/layout/ modules/resources/files/Cash_transfer_programming_in_ emergencies.pdf> (Accessed March 2014).

35. Barham T, Maluccio JA. Eradicating diseases: The effect of conditional cash transfers on vaccination coverage in rural Nicaragua. J Health Econ 2009;28:611-21

36. Programa "Alimentación libre de Gluten" < www.larevistadelceliaco. com.ar/agenda/corrientes-salta-y-jujuy-entregan-alimentos-paraceliacos> (Accessed March 2014).

37. Determinación de gluten en alimentos y la implementación de un sistema de gestión de calidad para la acreditación de la técnica. <www.cequimap.com.ar/foro/Gliadina.pdf> (Accessed March 2014).

38. Asociacion de celiacos de Extremadura. Proyecto ayudas economicas. < www.celiacos-ex.com/Cargar/BD/PROY_AYUDA ECONOM> (Accessed March 2014).

39. Pharmaceutical subsidy card. Ministry of Health New Zealand. $<$ www.health.govt.nz/your-health/conditions-and-treatments/ treatments-and-surgery/medications/pharmaceutical-subsidy-card> (Accessed March 2014).

40. Professional matters. Pharmaceut J 2013;291:582.
41. Details released for pharmacy gluten free-food service in Scotland.

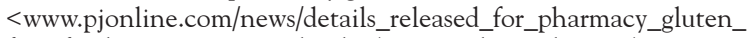
free_food_service_in_scotland $>$ (Accessed March 2014).

42. Manifiesto celiaco Mexico. $<$ http://manifiestoceliacomex.wordpress. com/manifiesto-celiaco-mexico/> (Accessed March 2014).

43. Morris S, Devlin N, Parkin D, et al. Economic Analysis in Health Care, 2nd edn. Hoboken: Wiley, 2007.

44. Tack GJ, Verbeek WH, Schreurs MW, et al. The spectrum of celiac disease: Epidemiology, clinical aspects and treatment. Nat Rev Gastroenterol Hepatol 2010;7:204-13.

45. Niewinski MM. Advances in celiac disease and gluten-free diet. J Am Diet Assoc 2008;108:661-72.

46. See J, Murray JA. Gluten-free diet: The medical and nutrition management of celiac disease. Nutr Clin Pract 2006;21:1-15.

47. De Irala-Estevez J, Groth M, Johansson L, et al. A systematic review of socio-economic differences in food habits in Europe: Consumption of fruit and vegetables. Eur J Clin Nutr 2000;54:706-14.

48. Clark AM, Duncan AS, Trevoy JE. Healthy diet in Canadians of low socioeconomic status with coronary heart disease: Not just a matter of knowledge and choice. Heart Lung 2011;40:156-63.

49. Parkin D. Comparing health service efficiency across countries. Oxford Rev Econ Policy 1989;5:75-88. 


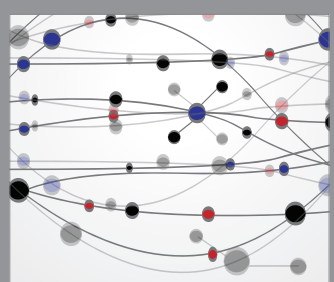

The Scientific World Journal
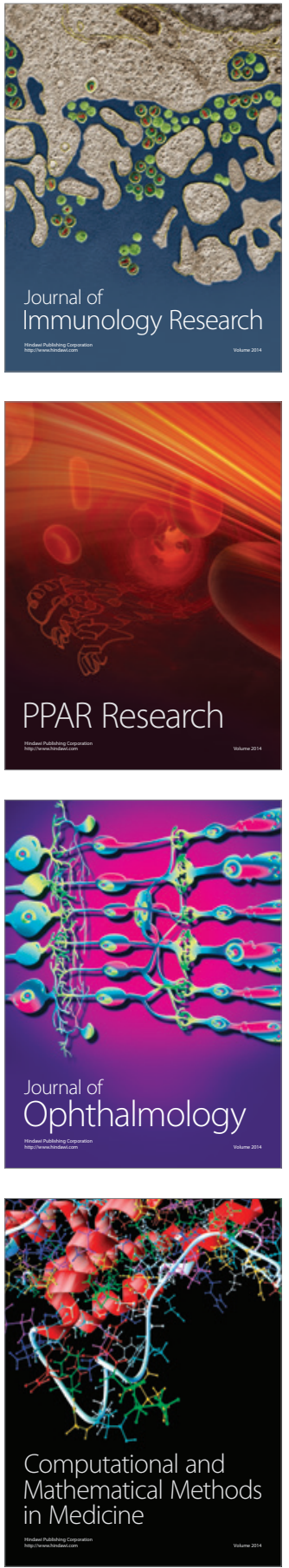

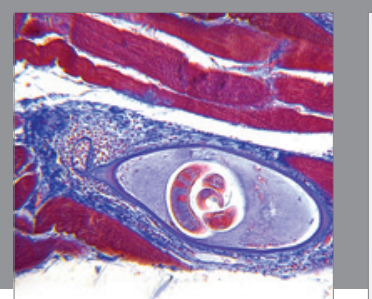

Gastroenterology Research and Practice

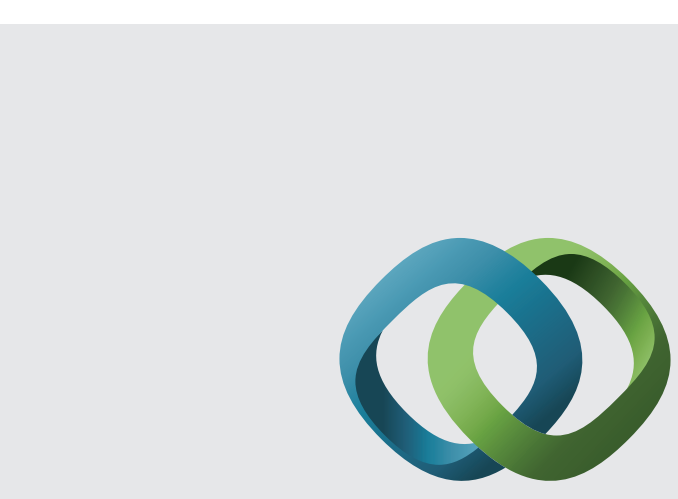

\section{Hindawi}

Submit your manuscripts at

http://www.hindawi.com
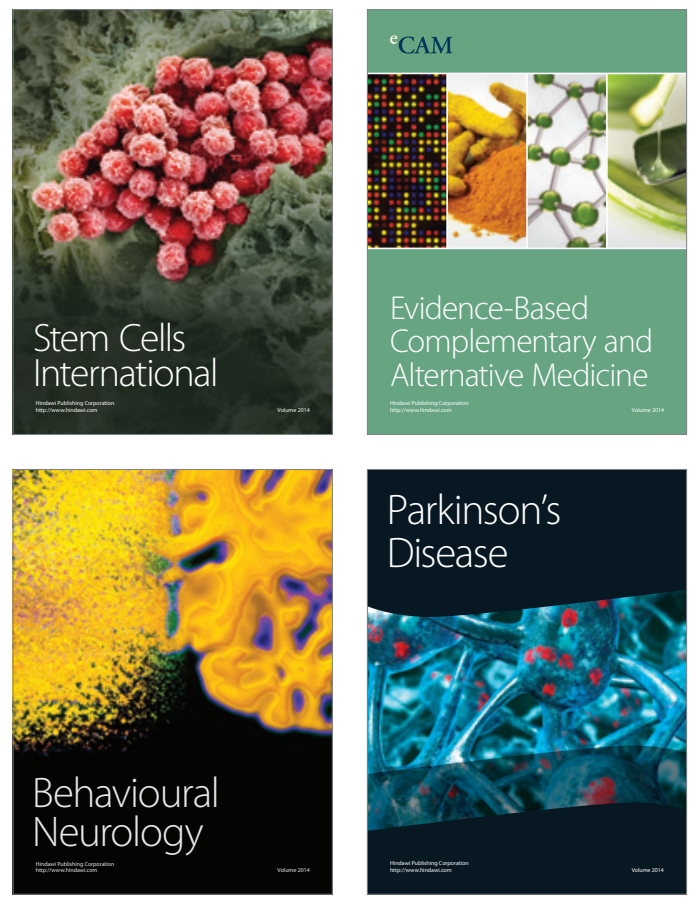
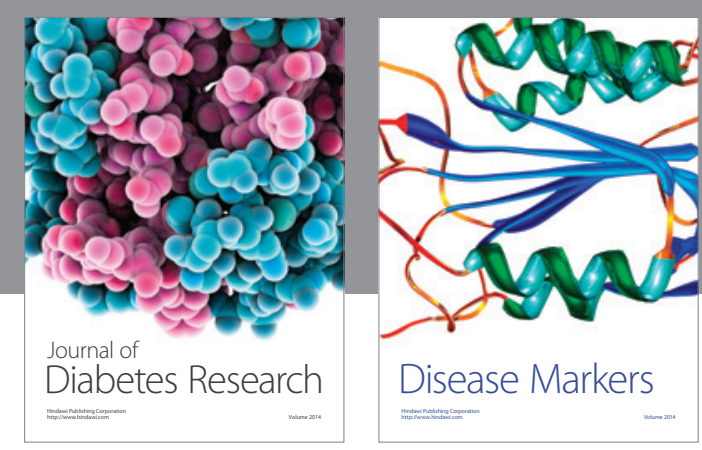

Disease Markers
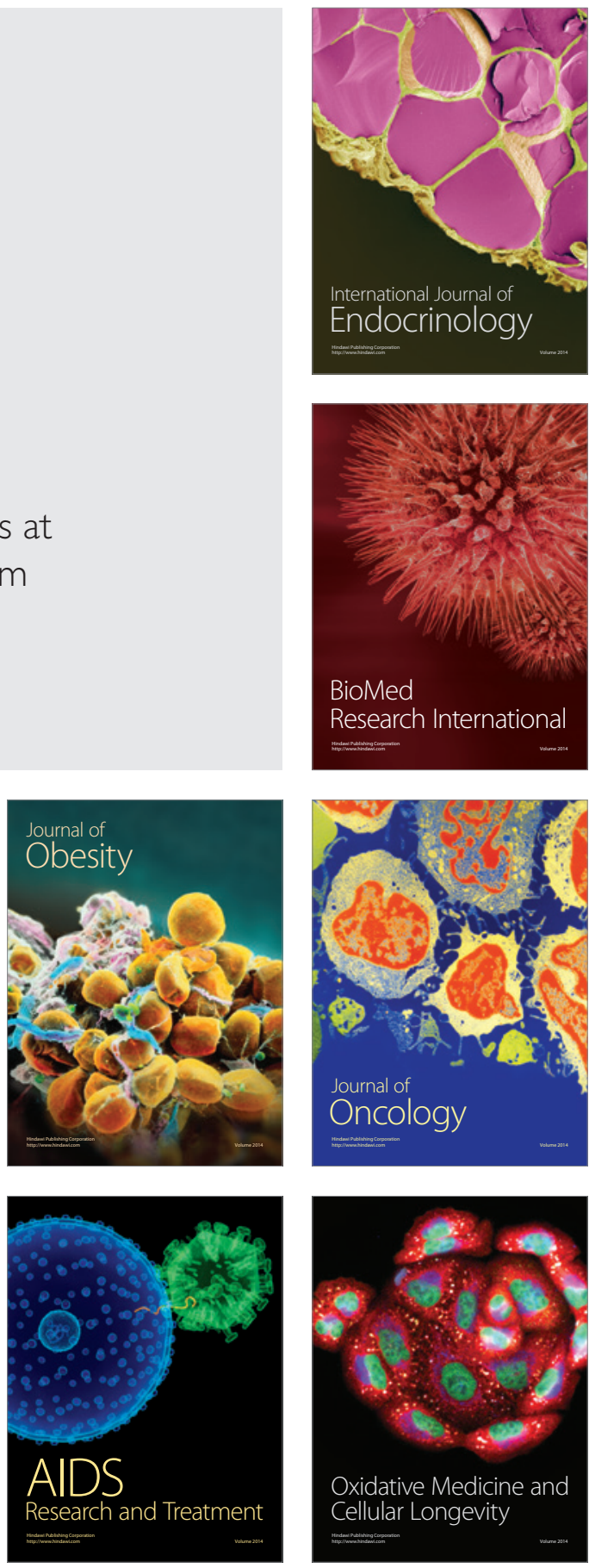